\title{
Sulfur Reduction in Acid Rock Drainage Environments
}

\author{
Anna P. Florentino, ${ }^{\dagger, \ddagger}$ Jan Weijma, ${ }^{\ddagger}$ Alfons J. M. Stams, ${ }^{\dagger, \S}$ and Irene Sánchez-Andrea*, ${ }^{\dagger}$ \\ ${ }^{\dagger}$ Laboratory of Microbiology, Wageningen University, Stippeneng 4, 6708 WE Wageningen, The Netherlands \\ ${ }^{\ddagger}$ Sub-department of Environmental Technology, Wageningen University, Bornse Weilanden 9, 6708 WG Wageningen, The \\ Netherlands \\ ${ }^{\S}$ CEB-Centre of Biological Engineering, University of Minho, Campus de Gualtar, 4710-057, Braga, Portugal
}

\section{Supporting Information}

ABSTRACT: Microbiological suitability of acidophilic sulfur reduction for metal recovery was explored by enriching sulfur reducers from acidic sediments at low $\mathrm{pH}$ (from 2 to 5) with hydrogen, glycerol, methanol and acetate as electron donors at 30 ${ }^{\circ} \mathrm{C}$. The highest levels of sulfide in the enrichments were detected at $\mathrm{pH} 3$ with hydrogen and $\mathrm{pH} 4$ with acetate. Cloning and sequencing of the $16 \mathrm{~S}$ rRNA gene showed dominance of the deltaproteobacterial sulfur-reducing genus Desulfurella in all the enrichments and subsequently an acidophilic strain (TR1) was isolated. Strain TR1 grew at a broad range of $\mathrm{pH}(3-7)$ and temperature $\left(20-50{ }^{\circ} \mathrm{C}\right)$ and showed good metal tolerance $\left(\mathrm{Pb}^{2+}\right.$, $\left.\mathrm{Zn}^{2+}, \mathrm{Cu}^{2+}, \mathrm{Ni}^{2+}\right)$, especially for $\mathrm{Ni}^{2+}$ and $\mathrm{Pb}^{2+}$, with maximal

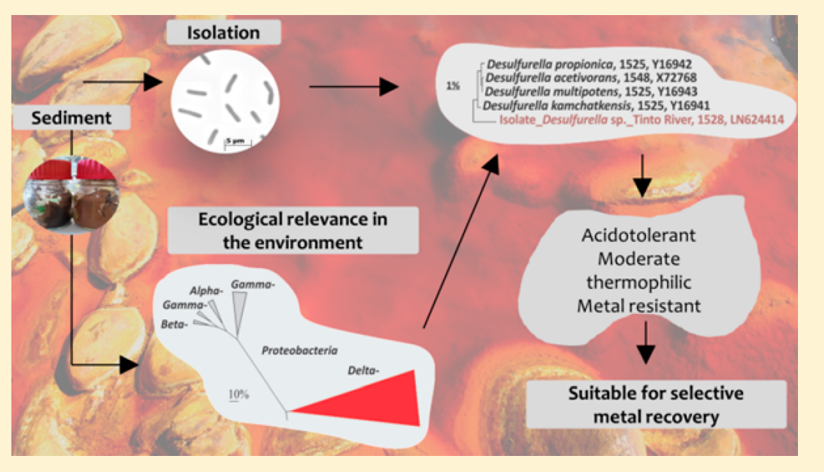
tolerated concentrations of 0.09 and $0.03 \mathrm{mM}$, respectively. Different sources of sulfur were tested in the enrichments, from which biosulfur showed fastest growth (doubling time of 1.9 days), followed by colloidal, chemical and sublimated sulfur (doubling times of 2.2, 2.5, and 3.6 days, respectively). Strain TR1's physiological traits make it a good candidate to cope with low $\mathrm{pH}$ and high metal concentration in biotechnological processes for treatment of metal-laden acidic streams at low and moderately high temperature.

\section{INTRODUCTION}

Sulfidogenic extremophiles are of scientific and technological interest ${ }^{1}$ because they extend the range of operating conditions of biotechnological processes, such as metal recovery. Depending on $\mathrm{pH}$ and its concentration, biogenic hydrogen sulfide precipitates a number of chalcophilic metals often present in industrial streams (e.g., $\mathrm{Cu}^{2+}, \mathrm{Zn}^{2+}, \mathrm{Ni}^{2+}, \mathrm{Pb}^{2+}, \mathrm{Cd}^{2+}$ and $\mathrm{Co}^{2+}$ ) as metal sulfides. ${ }^{2}$ (eq 1 )

$$
\mathrm{H}_{2} \mathrm{~S}+\mathrm{Me}^{2+} \rightarrow \mathrm{MeS}_{(\mathrm{s})}+2 \mathrm{H}^{+}
$$

Sulfate is often used as sulfur source for biosulfidogenesis to remove and recover metals from wastewater from the mining and metallurgical industry, ${ }^{3-5}$ as it is naturally present in many metal-rich waters, such as acid mine drainage. Microbiological sulfate reduction has been successfully applied at $\mathrm{pH}$ down to $2.5{ }^{6}$ which renders treatment of the acidic and metalliferous waters feasible. This type of water is generally characterized by a low content of organic matter ${ }^{7}$ and therefore, suitable electron donors need to be added for sulfate reduction. Organic waste materials may be used for low-rate, low-tech bioprocesses such as permeable reactive barriers, ${ }^{8}$ but their variable composition makes it less suitable for controlled, high-rate biogenic technologies. These require relatively pure bulk electron donors such as ethanol, glycerol, methanol, or hydrogen. ${ }^{7}$ Therefore, a critical bottleneck for widespread application of high-rate biogenic sulfide technologies is the cost of the electron donors. ${ }^{9}$ In that respect, elemental sulfur reduction is economically much more attractive than sulfate reduction, as only two electrons (eq 2) are needed instead of eight (eq 3) per sulfide formed.

$$
\begin{aligned}
& \mathrm{S}^{0}+2 \mathrm{H}^{+}+2 \mathrm{e}^{-} \rightarrow \mathrm{H}_{2} \mathrm{~S} \\
& \mathrm{SO}_{4}^{2-}+8 \mathrm{e}^{-}+10 \mathrm{H}^{+} \rightarrow \mathrm{H}_{2} \mathrm{~S}+4 \mathrm{H}_{2} \mathrm{O}
\end{aligned}
$$

Consequently, 4 times less electron donor needs to be added for sulfur reduction. Even though sulfate, the electron acceptor, is already present in metal contaminated waters; the additional costs of electron donors for sulfate reduction is higher than the costs of the combined addition of elemental sulfur and electron donors for sulfur reduction. ${ }^{10}$

Elemental sulfur has a low solubility in water $\left(5 \mu \mathrm{g} \mathrm{L} \mathrm{L}^{-1}\right.$ at 25 ${ }^{\circ} \mathrm{C}$ ), which may hamper its availability for microorganisms. The customary form of bulk elemental sulfur is sulfur flower that is mainly composed by $S_{8}$ rings and some polymeric sulfur that consists of chain-like macromolecules. ${ }^{11}$ This commercial product is normally obtained by the Claus-process or by sublimation. Colloidal sulfur produced by the acidification of

\section{Received: July 10, 2015}

Revised: September 10, 2015

Accepted: September 10, 2015

Published: September 10, 2015 
polysulfide or thiosulfate and microbiologically produced sulfur (biosulfur) by oxidation of sulfide, have smaller particle sizes and are more soluble in water, which could make them more accessible for microorganisms. ${ }^{12}$

A natural extreme environment, Tinto River (Huelva, southwestern Spain) presents a $\mathrm{pH}$ in the water column around 2.3 and high concentrations of heavy metals in solution (iron up to $20.2 \mathrm{~g} \mathrm{~L}^{-1}$, copper up to $0.70 \mathrm{~g} \mathrm{~L}^{-1}$, and zinc up to $\left.0.56 \mathrm{~g} \mathrm{~L}^{-1}\right){ }^{13} \mathrm{~A}$ novel acidophilic sulfate-reducing bacterium, Desulfosporosinus acididurans, ${ }^{14}$ and a novel fermenter, Microbacter margulisiae, have been recently isolated from these sediments, ${ }^{15}$ revealing that this environment is a promising source for novel acidophiles. We used sediments from Tinto River as a source of low $\mathrm{pH}$ adapted microorganisms and the suitability of those microorganisms for treatment of acidic and metal-laden wastewater was investigated. Acidophilic sulfurreducing microorganisms were enriched with various electron donors at low $\mathrm{pH}(\mathrm{pH} 2$ to 5) at mesophilic conditions (30 ${ }^{\circ} \mathrm{C}$ ). A sulfur-reducing bacterium belonging to the Desulfurella genus was isolated (strain TR1) and its applicability was tested at different conditions, e.g. $\mathrm{pH}$, temperature, utilization of electron donors, and growth in the presence of metals $\left(\mathrm{Cu}^{2+}\right.$, $\mathrm{Ni}^{2+}, \mathrm{Zn}^{2+}$, and $\mathrm{Pb}^{2+}$ ).

\section{MATERIAL AND METHODS}

Inoculum Source. Samples were collected from three sampling sites in Tinto River basin: JL, Los Frailes, and Moguer in March 2013. $J L$ site $\left(37^{\circ} 16^{\prime} 57.89^{\prime \prime} \mathrm{N}, 6^{\circ} 50^{\prime} 59.76^{\prime \prime} \mathrm{W}\right)$ is a dam point, relatively close to the origin, where wastewaters from the close municipality of Nerva join the river. Los Frailes point $\left(37^{\circ} 37^{\prime} 37.39^{\prime \prime} \mathrm{N}, 6^{\circ} 32^{\prime} 16.19^{\prime \prime} \mathrm{W}\right)$ is located in the middle course of the river. Moguer site $\left(37^{\circ} 16^{\prime} 28.70^{\prime \prime} \mathrm{N}, 6^{\circ}\right.$ $\left.50^{\prime} 12.868^{\prime \prime} \mathrm{W}\right)$ is located in the estuary part of the river. The $\mathrm{pH}$ values of the samples measured in situ were 2.6, 2.8, and 6.6 at the JL, Los Frailes, and Moguer sites, respectively. To increase the potential diversity of the inoculum, samples from the three sampling sites were pooled together. All the sediment samples $(\sim 10 \mathrm{~mL}$ each $)$ were mixed and the mixture was diluted in a $0.9 \%(\mathrm{w} / \mathrm{v}) \mathrm{NaCl}$ anoxic solution to a final volume of $50 \mathrm{~mL}$.

Microbial Diversity Analysis of the Inoculum (16S rDNA Gene Pyrosequencing). DNA was extracted from the sediment mixture and from the selected enrichments using the FastDNA SPIN Kit for Soil (Qbiogene, Carlsbad, CA), following the instructions of the manufacturer. The DNA was quantified with a Nanodrop spectrophotometer (Nanodrop Technologies, Wilmington, DE).

For pyrosequencing analysis of the inoculum, DNA concentration was adjusted to $10-20 \mathrm{ng} \mu \mathrm{L}^{-1}$ as template for PCR amplification. PCR was performed in a total volume of $100 \mu \mathrm{L}$ containing $1 \mathrm{X}$ HF PCR buffer, $0.2 \mathrm{mM}$ dNTPs, $2 \mathrm{U}$ $\mu \mathrm{L}^{-1}$ of Phusion Hot start II DNA polymerase (Promega, Madison, WI), $10 \mu \mathrm{M}$ of forward and the reverse primer mixture, $200 \mu \mathrm{M}$ of barcoded forward primer with titanium sequence adaptor, 338R-I+II (Biolegio BV, Nijmegen, The Netherlands), $0.2-0.4 \mathrm{ng} \mu \mathrm{L}^{-1}$ of template DNA and nuclease free water up to final volume. The amplification program consisted of an initial denaturation step at $98{ }^{\circ} \mathrm{C}$ for $30 \mathrm{~s}, 30$ cycles of denaturation at $98{ }^{\circ} \mathrm{C}$ for $10 \mathrm{~s}$, annealing at $56{ }^{\circ} \mathrm{C}$ for $20 \mathrm{~s}$ and elongation at $72{ }^{\circ} \mathrm{C}$ for $20 \mathrm{~s}$; and a final extension step at $72{ }^{\circ} \mathrm{C}$ for $10 \mathrm{~min}$. The size of the PCR products was checked by gel electrophoresis on an $1 \%(\mathrm{w} / \mathrm{v})$ agarose gel containing 1x SYBR Safe (Invitrogen, Carlsbad, CA). Negative control for PCR reactions were performed in parallel without addition of template, and consistently yielded no product. PCR products were purified with the High Pure Cleanup Micro Kit (Roche, Basel, Switzerland). Purified PCR products were mixed in equimolar amounts with a final DNA concentration of $100 \mathrm{ng}$ $\mu \mathrm{L}^{-1}$. The pooled amplicons were pyrosequenced using a FLX Genome Sequencer in combination with titanium chemistry (GATC-Biotech, Konstanz, Germany).

All sequence reads were processed by the NGS analysis pipeline of the SILVA rRNA gene database project (SILVAngs 1.0). ${ }^{16}$ Reads were aligned using SINA v1.2.11 against the SILVA SSU rRNA SEED and quality controlled. Identical reads were identified, the unique reads were clustered in operational taxonomic units (OTUs), on a per sample basis, applying identity criteria of 0.98 , and the reference read of each OTU was taxonomically classified. Phylogenetic reconstruction was performed by using the maximum likelihood, neighbor-joining and maximum parsimony algorithms in the ARB package and a consensus tree was generated with $A R B$ v6.0 software as described elsewhere. ${ }^{17}$

Screening Setup. An aliquot $(1 \mathrm{~mL})$ of the diluted mixture of sediment was added as inoculum to $120 \mathrm{~mL}$ serum bottles with $50 \mathrm{~mL}$ sterile anoxic basal medium, prepared based on the previous description of Stams et al. ${ }^{18}$ The medium was composed of $\left(\mathrm{g} \mathrm{L}^{-1}\right): 0.41 \mathrm{KH}_{2} \mathrm{PO}_{4} ; 0.53 \mathrm{Na}_{2} \mathrm{HPO}_{4} \cdot 2 \mathrm{H}_{2} \mathrm{O}$; $0.3 \mathrm{NH}_{4} \mathrm{Cl} ; 0.3 \mathrm{NaCl} ; 0.1 \mathrm{MgCl}_{2} \cdot 6 \mathrm{H}_{2} \mathrm{O} ; 0.11 \mathrm{CaCl}_{2} \cdot 2 \mathrm{H}_{2} \mathrm{O}$; and $1 \mathrm{~mL} \mathrm{~L}^{-1}$ of each acid and alkaline trace elements solution; 0.2 $\mathrm{mL} \mathrm{L} \mathrm{L}^{-1}$ vitamins; $0.1 \mathrm{~g} \mathrm{~L}^{-1} \mathrm{BBL}$ yeast extract (Becton Dickinson, Cockeysville, MA) and $1 \mathrm{~mL} \mathrm{~L}^{-1}$ resazurin sodium salt solution (Sigma-Aldrich, St. Louis, MI) ${ }^{18}$ In order to adjust the medium to low $\mathrm{pH}$ values, bicarbonate-buffer was omitted as described by Sánchez-Andrea et al. ${ }^{17}$ and $\mathrm{pH}$ was adjusted with $\mathrm{HCl}$ or $\mathrm{NaOH}$ before autoclaving to the different desired $\mathrm{pH}$ values. Serum bottles were sealed with butyl rubber stoppers (Rubber BV, Hilversum, The Netherlands) and flushed with a 1.5 atm $\mathrm{N}_{2} / \mathrm{CO}_{2}(80: 20, \mathrm{v} / \mathrm{v})$ headspace.

Enrichments were incubated statically in the dark at $30{ }^{\circ} \mathrm{C}$, and at $\mathrm{pH}$ varying from 2 to 5 . Acetate, glycerol and methanol were added as electron donors and carbon source from sterile anaerobic stock solutions to a final concentration of $5 \mathrm{mM} . \mathrm{H}_{2} /$ $\mathrm{CO}_{2}(80: 20, \mathrm{v} / \mathrm{v})$ was also tested with hydrogen as electron donor and $\mathrm{CO}_{2}$ as carbon source at $1.5 \mathrm{~atm}$. Elemental sulfur was added to all bottles in a concentration of $25 \mathrm{mM}$. Two control incubations were performed in the absence of additional external electron donor or elemental sulfur.

Screening Track. For this set of 40 bottles, sulfur reduction activity was regularly monitored by substrates consumption, sulfide production, possible products accumulation, $\mathrm{pH}$ change and planktonic cell counting (Supporting Information, Figure S1). Measurements were performed every 5 days. Acetate, glycerol, and methanol were quantified using an LKB highperformance liquid chromatograph (HPLC) with a Varian Metacarb $67 \mathrm{H} 300 \mathrm{~mm}$ column and $0.01 \mathrm{~N} \mathrm{H}_{2} \mathrm{SO}_{4}$ eluent at a

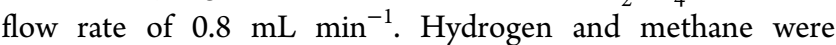
determined gas-chromatographically (Shimadzu, Kyoto, Japan), equipped with a Molsieve 13X column ( $2 \mathrm{~m}, \mathrm{ID} 2 \mathrm{~mm}$ ) and TCD detector. Sulfide concentrations in solution were determined by the photometric method using methylene blue as described previously by Cline. ${ }^{19}$ After incubation, some enrichments were selected and transferred to fresh medium with the same $\mathrm{pH}$ and electron donors, in duplicate.

The morphology of the cultures was followed and phase contrast microphotographs were taken with a Leica DM2000 microscope. The number of cells in the cultures was 
determined in technical duplicates by using a Petroff-Hausser counting chamber with a cell-depth of $0.02 \mathrm{~mm}$ and ruling pattern 1:400 $\mathrm{mm}^{2}$ (Hausser Scientific, Horsham, PA).

The cellular elemental sulfur reduction rates (cESRR) were calculated from the cell numbers and the formation of hydrogen sulfide adapted from Surkov, et al. ${ }^{20}$ as described in eq 4:

$$
\begin{aligned}
& \operatorname{cESRR}\left[\mu \operatorname{molS}^{0} \text { cell }^{-1} \text { day }^{-1}\right] \\
& \quad=\left(S_{\mathrm{i}}-S_{\mathrm{i}-1}\right)\left[\frac{C_{\mathrm{i}}+C_{\mathrm{i}-1}}{2}\right]^{-1}\left(t_{\mathrm{i}}-t_{\mathrm{i}-1}\right)^{-1}
\end{aligned}
$$

where $S, C$, and $t$ refer to the amount of hydrogen sulfide produced $(\mu \mathrm{mol})$, the total cell number and reaction time (day), respectively, at time intervals $i$ and $i-1$.

Microbial diversity analysis was performed in the selected enrichments. DNA was extracted from $10 \mathrm{~mL}$ culture as aforementioned. Extracted DNA was then amplified and cloned following the protocol described elsewhere. ${ }^{17}$ Inserts were screened by Amplified rDNA Restriction Analysis (ARDRA) using endonuclease $\mathrm{MspI}\left(1 \mathrm{U}, 3.5 \mathrm{~h}, 37^{\circ} \mathrm{C}\right.$ ) and grouped according to the restriction patterns obtained. Two members of each group were then sequenced at GATC Biotech AG, Konstanz, Germany.

Solid Media Development and Isolation. Common solid media for sulfur reducers are standardly based on polysulfide. $^{21,22}$ Due to its instability at low $\mathrm{pH}$ and its unspecificity for true sulfur reducers, new solid medium needed to be developed. Four different sulfur types were used as electron acceptors: chemical sulfur obtained by Claus-process from the manufacture of barium and strontium carbonate (Boom, Netherlands); biosulfur obtained from a process for biological sulfide oxidation (Industriewater Eerbeek, Eerbeek, The Netherlands); purified sulfur obtained by sublimation (Sigma-Aldrich, St. Louis, MI); and colloidal sulfur (SigmaAldrich, St. Louis, MI). They were then added to a final concentration of $0.4 \%(\mathrm{w} / \mathrm{v})$ to a $2 \%(\mathrm{w} / \mathrm{v})$ agar medium using acetate $(5 \mathrm{mM})$ as electron donor. Both techniques, streak plate and Hungate tubes were tested. For the plates, $100 \mu \mathrm{L}$ of the culture were spread on to the surface of the plates and incubated in anaerobic jars pressurized with $\mathrm{N}_{2} / \mathrm{CO}_{2}(80: 20, \mathrm{v} /$ v). For the tubes, $1 \mathrm{~mL}$ of the culture was transferred to $9 \mathrm{~mL}$ of a molten agar medium in Hungate tubes pressurized with $\mathrm{N}_{2} / \mathrm{CO}_{2}(80: 20, \mathrm{v} / \mathrm{v})$. Anaerobic jars and tubes were incubated in the dark at $30{ }^{\circ} \mathrm{C}$ until colony development was observed.

Isolation was performed by combining colonies growth in solid medium and serial dilution with antibiotic addition in concentrations of 5 and $100 \mu \mathrm{g} \mathrm{mL}^{-1}$. The purity of the cultures was checked: (i) microscopically, (ii) by $16 \mathrm{~S}$ rRNA gene sequences analysis of around 100 clones grouped by ARDRA (as described in the section Enrichments Selection), and (iii) by inoculation into fresh medium with $1 \mathrm{~g} \mathrm{~L}^{-1}$ yeast extract and $5 \mathrm{mM}$ glucose to detect contamination by fermenters.

Sulfur Sources Comparison. Due to the insolubility of sulfur, $^{23}$ the four different sources of elemental sulfur described above were tested to check which one could promote higher rates of sulfur reduction. Acetate $(5 \mathrm{mM})$ was used as electron donor and $25 \mathrm{mM}$ of the different sulfur sources were added in each bottle. The highly enriched culture on acetate at $\mathrm{pH} 4$, socalled [Acet, $\mathrm{pH} 4$ ] obtained in the previous step was used as inoculum. Sulfur reduction activity was regularly monitored by acetate consumption and sulfide production. Measurements were performed every 2 days. The analyses were carried out in biological duplicates and the results were averaged.

Metals Tolerance Analysis. Tolerance to four metals often found in metalliferous wastes (copper, nickel, lead, and zinc) was tested for the obtained isolate. Concentrations of free metal ions were chosen in the range of reported toxic concentrations of metals for bacteria involved in the sulfur cycle. ${ }^{24}$ To account with the metal precipitation due to phosphate or reducing agent present in the medium, the concentration of free metals was recalculated measuring the free metal concentration after their addition to the medium.

Copper, lead, nickel, and zinc chloride salt solutions were used to get the following range of maximum exposure concentrations: copper $0.1-0.5 \mathrm{mM}$, lead $0.02-0.04 \mathrm{mM}$, nickel $0.3-10.2 \mathrm{mM}$, and zinc $0.02-1.2 \mathrm{mM}$. Bottles that did not contain inoculum or metal were prepared as controls. Acetate was used as electron donor and $\mathrm{pH}$ in the cultures was adjusted to 3 before inoculation. Experiments were conducted in duplicate and cultures were incubated statically for one month at $50{ }^{\circ} \mathrm{C}$ (optimum temperature for the isolate). Samples were taken periodically for monitoring of sulfide production and electron donor consumption. Soluble metals concentrations were determined at time zero and after 28 days of incubation. Free metal ions were quantified with Spectroquant cell tests (Merck Millipore, Darmstadt, Germany).

Other Physiological Tests. Temperature range for growth of the isolate was assessed from 15 to $60{ }^{\circ} \mathrm{C}$ as well as $\mathrm{pH}$ range from 2.8 to 8 , using $5 \mathrm{mM}$ of acetate as electron donor and 25 $\mathrm{mM}$ of elemental sulfur as electron acceptor. The analyses were carried out in biological duplicates and the results averaged. The following electron donors were tested for growth at a final concentration of $5 \mathrm{mM}$ at $\mathrm{pH} 4$ and at $30{ }^{\circ} \mathrm{C}$ : acetate, arginine, benzoate, butyrate, caproate, ethanol, formate, fructose, fumarate, glucose, glycerol, glycine, hexadecane, hydrogen, isobutyrate, lactate, leucine, lysine, malate, methanol, palmitate, peptone, propionate, pyruvate, starch, stearate, sucrose, and succinate. Sulfur as substrate for disproportionation was also tested. Growth rates were assessed by Gompertz model. ${ }^{25}$

Nucleotide Sequence Accession Numbers. The cloned $16 \mathrm{~S}$ rRNA gene sequences from the enrichments, the isolate sequence and the sequences obtained from the pyrosequencing analysis were deposited in the EMBL database and are available under accession numbers LN624405-LN624412, LN624414, LN624416, LN649261-LN649263, LN680091, and LN680092.

\section{RESULTS}

Microbial Diversity in Tinto River Sediments Used As Inoculum. Analysis of the $16 \mathrm{~S}$ rDNA gene amplicons of the sediment mixture yielded 10852 sequences, from which 10792 reads passed the quality control with an average length of 330 nucleotides. The individual phylotypes could be clustered (identity criteria of 0.98 ) into 3595 tag phylotypes, representing 8 known phyla or candidate division. The three most representative phyla were Firmicutes (60\% of the sequences), Proteobacteria (21\%), and Acidobacteria (13\%). Actinobacteria, Cyanobacteria, Bacteriodetes, Nitrospirae, and Candidate division TM7 represented together around $6 \%$ of the diversity. At the genus level, sequences clustered into 322 genera (Supporting Information, Table S1). About $6 \%$ of all the sequences could not be identified at the genus level and were classified at the next highest possible resolution level. Some sequences belonged to microorganisms known to perform sulfur 


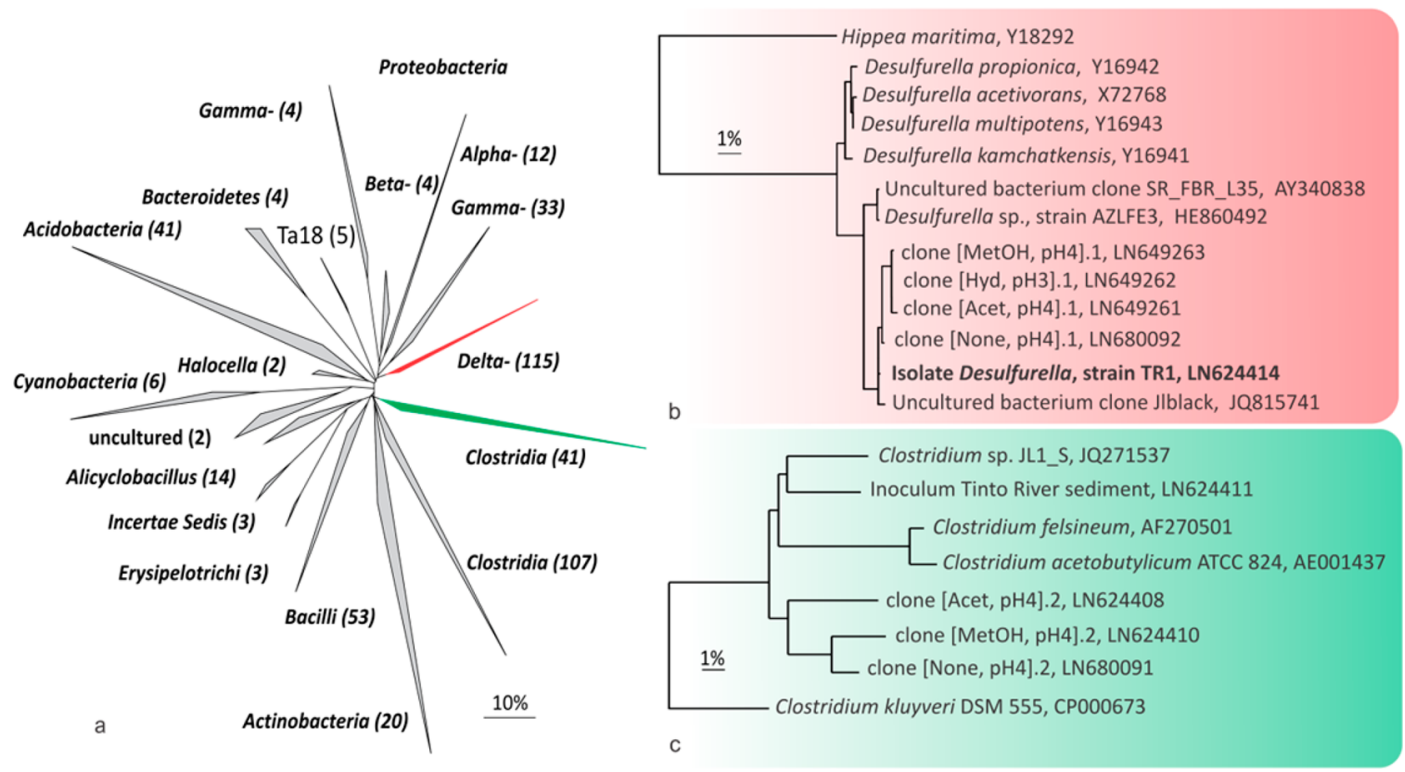

Figure 1. a-c. Phylogenetic affiliations of $16 \mathrm{~S}$ rDNA sequences obtained (a) from the inoculum and from the enrichments as (b) dominant closest related and (c) main contaminant closest related sequences. The trees display a consensus from neighbor-joining, maximum likelihood and maximum parsimony algorithms. Bars represent 10 (in a) or 1 (in b and c) changes per site or $100 \%$ divergence in sequence. Numbers of representative sequences per group are represented in parentheses.

reduction, ${ }^{13}$ such as Desulfosporosinus spp., Thermoplasma spp., or Acidithiobacillus ferrooxidans, showing the potential of the inoculum to perform sulfur reduction at low $\mathrm{pH}$. Sequences belonging to the obligate sulfur reducer genus Desulfurella were also identified, representing about $3 \%$ of the proteobacterial sequences and about $0.6 \%$ of the bacterial sequences of the inoculum used. The main groups identified in the inoculum are represented in Figure 1a.

Sulfur Reduction Activity of Enrichments. Sulfide production was detected in the cultures incubated at the range of $\mathrm{pH} 3$ to 5 but not at $\mathrm{pH} 2$ (Supporting Information, Table S2). $\mathrm{CO}_{2}$ and $\mathrm{H}_{2} \mathrm{~S}$ were the only products detected in the cultures, indicating complete oxidation of the organic compounds. Methane was not detected in the headspace of any culture. Incubations with acetate and hydrogen yielded the highest production of sulfide in all conditions in which growth was observed. When glycerol and methanol were added as electron donors, growth was observed and sulfide was weakly produced. In this case, no consumption of the substrates was detected.

From the 40 bottles, a preselection was made prioritizing, per substrate, the lowest $\mathrm{pH}$ with the highest production of sulfide. Accordingly, the following conditions were selected and transferred to fresh medium in a second set of enrichments: $\mathrm{pH} 3$ with hydrogen as electron donor ([Hyd, $\mathrm{pH} 3]$ ), and $\mathrm{pH} 4$ with acetate ([Acet, $\mathrm{pH} 4])$, in which the production of $\mathrm{H}_{2} \mathrm{~S}$ reached 16.4 and $10.9 \mathrm{mM}$, with 10.5 and $4.6 \mathrm{mM}$ of acetate consumption, respectively; $\mathrm{pH} 4$ with methanol ([MetOH, $\mathrm{pH} 4]$ ), and one group without external electron donor at $\mathrm{pH} 4$ ([None, pH4]), in which sulfide did not reach more than 2 $\mathrm{mM}$.

At the end of the second set of enrichments, the sulfide concentration reached 9.3 and $11.6 \mathrm{mM}$ in the enrichments [Acet, pH4] and [Hyd, pH3], respectively (Figure 2). For the enrichment with sulfur as single substrate [None, $\mathrm{pH} 4$ ], the maximum sulfide production was around $1.9 \mathrm{mM}$. Similar sulfide concentration $(1.0 \mathrm{mM})$ was detected in the enrichment

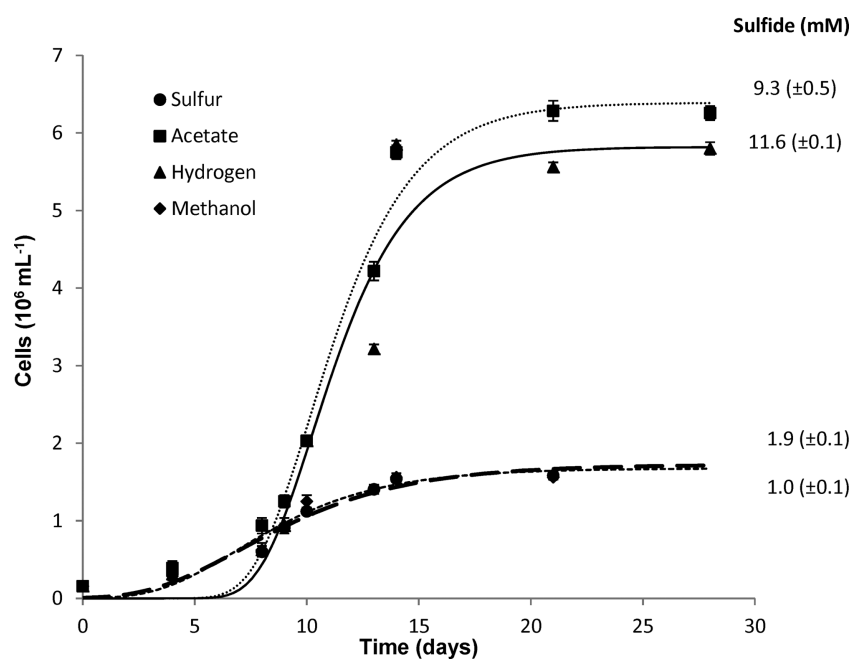

Figure 2. Number of cells and sulfide production reached in the secondary enrichments incubated at $30{ }^{\circ} \mathrm{C}$ with different electron donors. The values on the right side refer to the final value of sulfide production in the respective culture in the represented in the curve. The cells counting analysis was carried out in technical duplicates, and the sulfide production measurement was performed in biological duplicates. The results were averaged and the standard deviation is shown.

with methanol [MetOH, pH4], and consistently, no methanol consumption was detected. Since no external electron donor was present or consumed in both cases, the sulfide production in those cultures is not coupled to the oxidation of substrates in sulfur reduction. In these cultures, 0.7 and $0.5 \mathrm{mM}$ of sulfate was also formed, respectively.

Under the microscope, different cell morphologies were observed in the cultures, but short rod-shaped bacteria were predominant in all of them. Sulfide production paralleled microbial growth, with maximum culture cell densities for the enrichments [Acet, pH4], [Hyd, pH3], [MetOH, pH4] and 
[None, pH4] being $6.3 \times 10^{6}, 6.0 \times 10^{6}, 1.6 \times 10^{6}$, and $2.0 \times$ $10^{6}$ cells $\mathrm{mL}^{-1}$, respectively (Figure 2). Application of the Surkov equation indicated rates of $0.48 \mathrm{fmol} \mathrm{cell}^{-1} \mathrm{day}^{-1}$ for the enrichment [Hyd, pH3] and 0.36, 0.45, and $0.47 \mathrm{fmol} \mathrm{cell}^{-1}$ $\mathrm{day}^{-1}$ for the enrichments [Acet, $\mathrm{pH} 4$ ], [MetOH, pH4], [None, pH4], respectively. No attempts were made to count cells attached to elemental sulfur particles, so that the counts considered only planktonic cells.

Microbial Community Analysis of the Enrichments. DNA was extracted from the four selected enrichments. Amplification of both archaeal and bacterial 16S rDNA genes was done. Only amplification of the bacterial genes gave positive results indicating that no archaeal communities developed in the conditions tested. A rather low bacterial diversity was observed for all the enrichments, with 2, 3, 4, and 2 OTUs for the enrichments [None, pH4]; [Acet, pH4]; [MetOH, pH4]; and [Hyd, $\mathrm{pH} 3]$, respectively (Table 1).

Table 1. Phylotypes in the Selected Enrichments ${ }^{a}$

\begin{tabular}{|c|c|c|c|}
\hline sample & $\begin{array}{l}\text { no. } \\
\text { sequences }\end{array}$ & $\begin{array}{c}\text { closest organism (acc. } \\
\text { number) }\end{array}$ & $\begin{array}{l}\text { identity } \\
(\%)\end{array}$ \\
\hline \multirow[t]{2}{*}{ [None, $\mathrm{pH} 4]$} & 30 & Desulfurella sp. (LN680092) & 98 \\
\hline & 6 & Clostridium sp.(LN680091) & 99 \\
\hline \multirow[t]{3}{*}{ [Acet, $\mathrm{pH} 4]$} & 17 & Desulfurella sp. (LN649261) & 98 \\
\hline & 3 & Clostridium sp. (LN624408) & 97 \\
\hline & 1 & Bacillus sp. (LN624407) & 98 \\
\hline \multirow[t]{4}{*}[\mathrm{MetOH},\mathrm{pH}4]{} & 11 & Desulfurella sp. (LN649263) & 98 \\
\hline & 2 & $\begin{array}{l}\text { Acidobacteria bacterium } \\
\text { (LN624405) }\end{array}$ & 94 \\
\hline & 2 & Clostridium sp. (LN624410) & 94 \\
\hline & 5 & $\begin{array}{l}\text { Acidocella aromatica } \\
(\text { LN624406) }\end{array}$ & 99 \\
\hline \multirow[t]{2}{*}{ [Hyd, pH 3] } & 18 & Desulfurella sp. (LN649262) & 98 \\
\hline & 1 & Clostridium sp. (LN624409) & 95 \\
\hline
\end{tabular}

${ }^{a}$ Accession numbers: LN624405-LN624410, LN649261-LN649263, LN680091 and LN680092.

Sequences belonging to the sulfur-reducing bacterial genus Desulfurella (Deltaproteobacteria), dominated all the clone libraries. A phylogenetic reconstruction of the closest organisms reveals that related sequences to our Desulfurella strain do not cluster together with the four species already described in this genus (Figure 1b). Other microorganisms were coenriched, such as Clostridium and Bacillus with acetate; Acidobacteria, Clostridium, and Acidocella with methanol; and Clostridium with hydrogen, mainly related to fermentative metabolism. Clostridium sp. appeared as the main contaminant in the primary enrichments and remained as the only contaminant (Figure 1c) in further transfers up to the addition of vancomycin $(5 \mu \mathrm{g}$ $\mathrm{mL}^{-1}$ ).

Solid Medium and Isolation of Desulfurella sp., Strain TR1. Different sulfur sources (chemical, sublimated, colloidal, and biosulfur) were tested for solid medium. Incubation with colloidal sulfur gave the best results, with visible growth of small whitish colonies $(0.5-1.0 \mathrm{~mm}$ diameter) after one month of incubation (Supporting Information, Figure S2). All the other forms of elemental sulfur did not show growth on solid medium. Therefore, due to its bioavailability and solubility properties, colloidal sulfur was selected as sulfur source for isolation of sulfur reducers at low $\mathrm{pH}$ on solid medium.
The selected enrichments performing sulfur reduction ([Hyd, $\mathrm{pH} 3]$ and [Acet, $\mathrm{pH} 4]$ ) were inoculated in this medium. Analysis of the $16 \mathrm{~S} \mathrm{rDNA}$ gene of the colonies growing on agar showed that in all the conditions studied, Clostridium spp. sequences appeared as the major contaminant. As a strategy to avoid this contamination with Gram-positive bacteria, the solid medium was supplemented with $5 \mu \mathrm{g} \mathrm{mL}^{-1}$ vancomycin and the medium was inoculated again. After antibiotic addition, Clostridium sequences were not further detected when 96 clones were analyzed by ARDRA profiles. However, another contaminant was detected, with $5 \%$ of the sequences belonging to Sediminibacterium genus, $99 \%$ related to Sediminibacterium ginsengisoli (accession number: EF067860). One Desulfurella colony was transferred to liquid medium and two serial dilutions were performed with vancomycin $(100 \mu \mathrm{g}$ $\mathrm{mL}^{-1}$ ) to avoid Sediminibacterium contamination. Finally, a pure culture (strain TR1) was obtained.

Desulfurella sp. Strain TR1 Phylogeny and Physiology. Growth of strain TR1 was detected in a wide range of temperature varying from 25 to $50{ }^{\circ} \mathrm{C}$ with an optimum at 50 ${ }^{\circ} \mathrm{C}$; at $55{ }^{\circ} \mathrm{C}$ no growth occurred (Supporting Information, Figure S3). Growth occurred at $\mathrm{pH}$ varying from 3 to 7 with an optimum at pH 6 (Supporting Information - Figure S4). In cultures where growth occurred, the final $\mathrm{pH}$ of the medium stated around 5.5-6. The isolated strain was able to grow heterotrophically in the presence of sulfur with acetate, stearate, lactate, pyruvate, and arginine; and autotrophically with $\mathrm{H}_{2}$ / $\mathrm{CO}_{2}$. As expected, methanol and glycerol were not used by the bacterium, neither benzoate, butyrate, caproate, ethanol, formate, fumarate, glucose, glycine, hexadecane, isobutyrate, leucine, lysine, malate, palmitate, peptone, propionate, starch sucrose, and succinate were used. It also grew by disproportionation of elemental sulfur and by reduction of thiosulfate (data not shown).

The 16S rDNA sequence of the isolate showed 98\% identity with other Desulfurella species, not clustering together with them (Figure 1b). The genus Desulfurella comprises four species so far: D. acetivorans, ${ }^{26}$ D. multipotens, ${ }^{27} D$. kanchatkensis, and D. propionica, $^{28}$ and they share $99 \% 16 \mathrm{~S}$ rDNA similarity between them. This, together with the threshold established for species $(98.7 \%),{ }^{29}$ suggests that our isolate represents a novel species within the Desulfurella genus. Strain TR1 shares 99\% similarity with strain AZLFE3, isolated from a hydrothermal spring system in the Mexican Volcanic Axis, Los Azufres. ${ }^{30}$ Unfortunately, no physiological description of that strain is available.

Reduction of Different Sulfur Sources. To study the influence of the type of elemental sulfur on the sulfur reduction rate of the isolate, different forms of elemental sulfur were also tested in duplicates with acetate as electron donor at $\mathrm{pH} 4$ (Figure 3). High final sulfide production (between 12.1 and $13.5 \mathrm{mM}$ ) was found for all sulfur forms, except for the sublimated sulfur in which $8.3 \mathrm{mM}$ was the maximum detected. Biosulfur promoted the fastest growth of the culture, with doubling time of 1.9 day, followed by colloidal sulfur, and chemical sulfur with doubling times of 2.2 and 2.5 respectively and accordingly, sublimated sulfur showed the highest doubling time (3.6 days).

Sensitivity to Metals. Growth and activity of Desulfurella strain TR1 were affected by metal ions $\left(\mathrm{Cu}^{2+}, \mathrm{Ni}^{2+}, \mathrm{Pb}^{2+}\right.$ and $\mathrm{Zn}^{2+}$ ), but still occurred. A common observation was that with increasing metal concentration, the lag phase of the cultures increased, and the final sulfide production decreased, which 


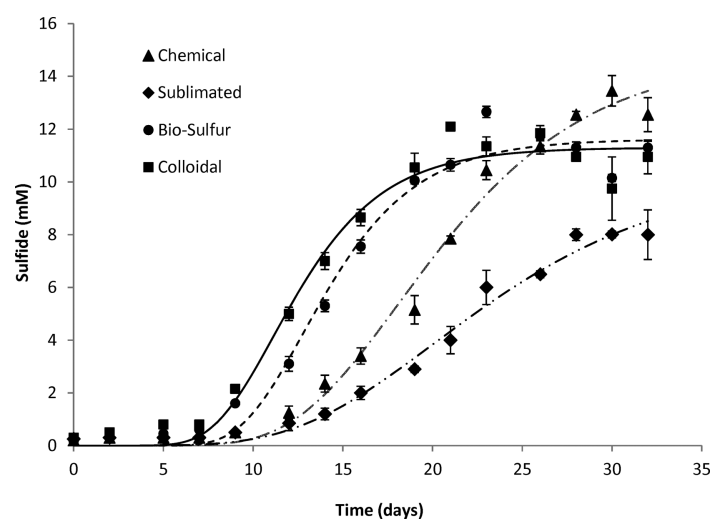

Figure 3. Sulfide production of enrichments inoculated with different forms of elemental sulfur as electron acceptor and acetate as electron donor at $30{ }^{\circ} \mathrm{C}$. The analyses were carried out in biological duplicates and the results averaged.

coincided with a decrease in the total acetate consumption (Figure $4 a-d$ ) and by a decrease in metal precipitation levels
(Table 2). In cultures where growth occurred, the $\mathrm{pH}$ of the medium increased from $\mathrm{pH} 3$ to 5 .

Copper precipitation occurred in all the concentrations tested. Even though the precipitation decreased about 27\% from initial measured concentrations of $0.1-0.5 \mathrm{mM}$, acetate consumption by Desulfurella strain TR1 did not differ much and cell growth occurred in both cultures, showing a good tolerance of the isolate to copper, one of the most toxic metals present in industrial wastewaters. Lead was completely precipitated by the sulfide produced at initial concentrations of 0.02 and $0.03 \mathrm{mM}$. After metal precipitation, an increase of free sulfide was detected, confirming the activity of the culture. Nickel was tolerated by Desulfurella strain TR1 up to an initial concentration of $0.9 \mathrm{mM}$, when acetate was almost depleted in 28 days, and free sulfide and cells were detected. For zinc, 0.09 $\mathrm{mM}$ was the maximum added concentration at which acetate consumption, free sulfide and cell growth were observed.

Consequently, the rates for acetate or sulfur consumption were also affected. The controls showed rates of 0.31 and 0.07 $\mathrm{mM}$ day $^{-1}$ of acetate and sulfur consumption, respectively. These rates decreased for the maximum tolerated concentration

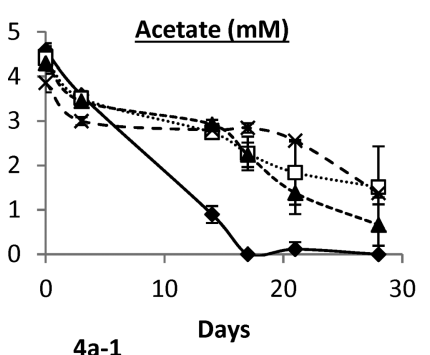

$4 a-1$
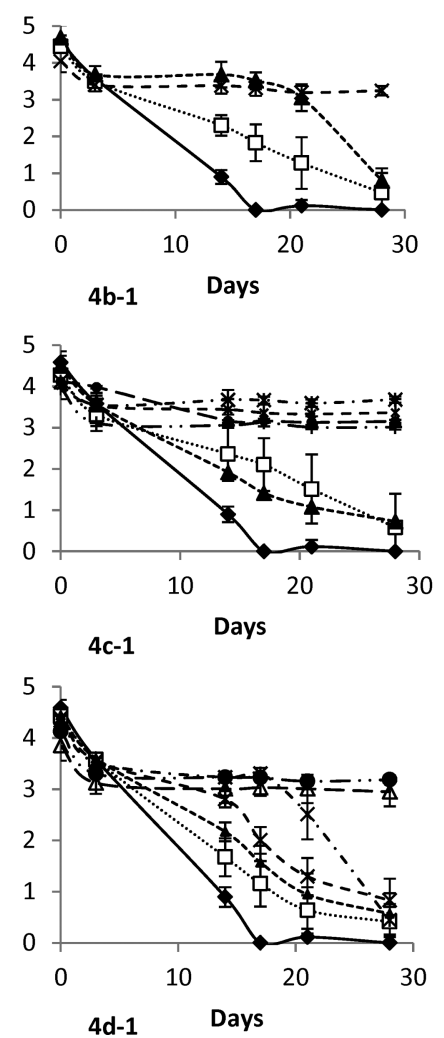
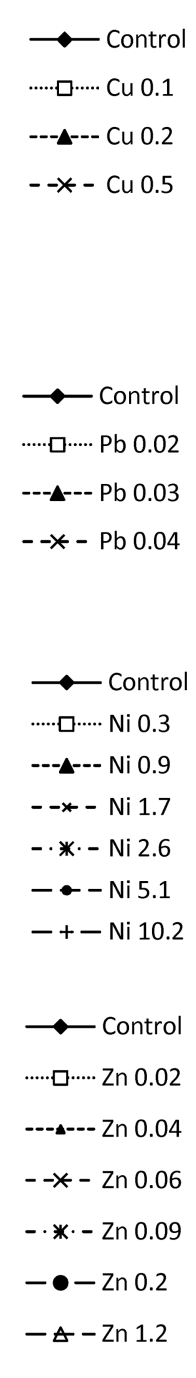
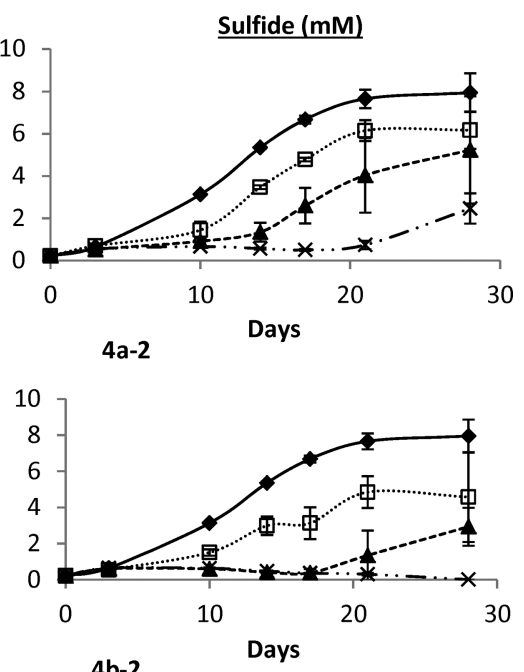

$4 b-2$

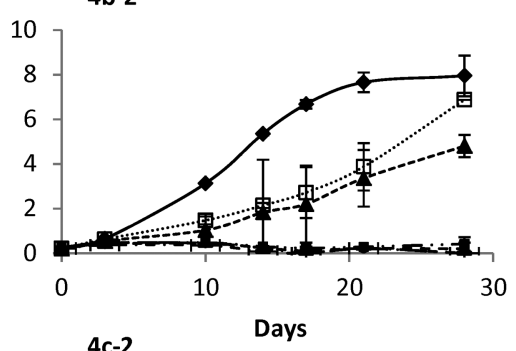

4c-2

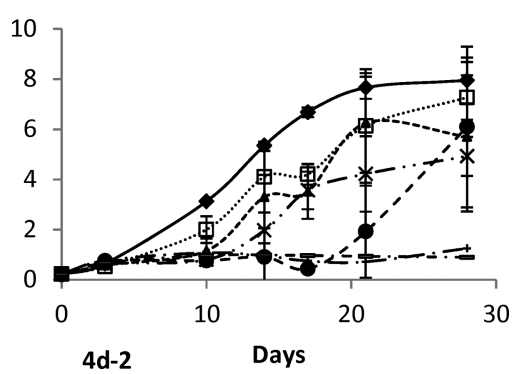

Figure 4. a-d. Evolution of acetate (1) and sulfide (2) concentrations (mM) during incubation of Desulfurella strain TR1 in the presence of (a) copper in a range from 0.1 to $0.5 \mathrm{mM}$; (b) lead from 0.02 to $0.04 \mathrm{mM}$; (c) nickel from 0.3 to $10.2 \mathrm{mM}$ and (d) zinc in a range from 0.02 to $1.2 \mathrm{mM}$. Data points are mean values of replicate cultures and error bars show the range. 
Table 2. Percentage of Bio-Precipitation for the Different Concentrations of Metals Added and the Maximum Tolerated Studied Concentration (MTSC) of Each Metal for Desulfurella Strain TR1

$\begin{array}{lccc}\text { metal } & \text { initial concentration }(\mathrm{mM}) & \text { bioprecipitation }(\%) & \text { MTSC }(\mathrm{mM}) \\ \text { copper } & 0.1 & 97.2( \pm 1.1) & >0.5 \\ & 0.2 & 87.6( \pm 7.8) & \\ & 0.5 & 69.7( \pm 6.6) & \\ \text { lead } & 0.02 & 100.0( \pm 0.0) & 0.03 \\ & 0.03 & 100.0( \pm 0.0) & \\ & 0.04 & 4.6( \pm 5.0) & \\ \text { nickel } & 0.3 & 77.5( \pm 8.2) & 0.9 \\ & 0.9 & 52.9( \pm 4.2) & \\ & 1.7 & 7.1( \pm 0.8) & \\ & 2.6 & 4.1( \pm 2.9) & \\ & 5.1 & 2.4( \pm 1.1) & \\ & 10.2 & 0.2( \pm 1.6) & \\ & & 60.9( \pm 2.7) & 0.09 \\ \text { zinc } & 0.02 & 63.6( \pm 6.1) & \\ & 0.04 & 36.5( \pm 4.7) & \\ & 0.06 & 32.3( \pm 0.9) & \\ & 0.09 & 4.0( \pm 0.1) & \\ & 0.2 & 0.8( \pm 0.2) & \end{array}$

per metal. Rates $\left(\mathrm{mM} \mathrm{day}{ }^{-1}\right)$ for acetate and sulfur consumption were: 0.53 and 0.01 at $0.5 \mathrm{mM}$ of copper; 0.05 and 0.014 at $0.03 \mathrm{mM}$ of lead; 0.23 and 0.05 at $0.9 \mathrm{mM}$ of nickel; and 0.11 and 0.03 at $0.09 \mathrm{mM}$ of zinc.

\section{DISCUSSION}

Our results showed that elemental sulfur reduction with different electron donors occurred at low $\mathrm{pH}$ when an inoculum from a natural acidic environment, Tinto river sediments, was used. Sulfur reduction activity with the highest sulfide production levels occurred in the primary enrichments with $\mathrm{H}_{2} / \mathrm{CO}_{2}$ and acetate at $\mathrm{pH}$ values down to 3 and 4 , respectively. No methane production or archaeal communities were detected. Thus, no competition for the electron donors added took place between sulfur reducers and methanogens. As the dominant sequences detected in all the enrichments were related to a strain in the sulfur-reducing genus Desulfurella, isolation strategies targeted it as the key player in the sulfurreducing enrichments at low- $\mathrm{pH}$.

The isolation of a Desulfurella strain at low $\mathrm{pH}$ and moderate temperature with different substrates was unexpected. Strain TR1 was able to grow at temperature as low as $20{ }^{\circ} \mathrm{C}$ and $\mathrm{pH}$ as low as 3, unlike other members of the Desulfurella genus. All described members of this genus are thermophiles with temperature optima between 50 and $60{ }^{\circ} \mathrm{C}$, with minimum temperature for growth stated at $33{ }^{\circ} \mathrm{C}$ for D. propionica, ${ }^{28}$ and 40,42 , and $44{ }^{\circ} \mathrm{C}$ for D. kamchatkensis, ${ }^{28}$ D. multipotens ${ }^{27}$ and D. acetivorans, ${ }^{26}$ respectively. Other Desulfurella spp. are neutrophilic with $\mathrm{pH}$ optima between 6.4 and $7.2,^{26-28}$ and minimum $\mathrm{pH}$ for growth is stated at 4.3 for D. acetivorans. ${ }^{26}$ During growth of Desulfurella strain TR1, the $\mathrm{pH}$ of the unbuffered medium increased from 3 up to 5 . Although there is an increase in $\mathrm{pH}$ in the medium during growth, the isolate started growing at $\mathrm{pH} 3$, which certainly implies proton resistance with sulfide production starting at this low $\mathrm{pH}$.
Described acidophilic sulfate-reducing bacteria (SRB) of the genus Desulfosporosinus (D. acidiphilus and D. acididurans) can grow at a minimum $\mathrm{pH}$ of 3.6 and 3.8 respectively. ${ }^{14,31}$ However, D. acididurans was still active when tested in a reactor treating acidic waters at $\mathrm{pH}$ as low as $2.5^{6}$ The high proton resistance of Desulfurella strain TR1 represents a new opportunity to develop a biotechnological process based on acidophilic sulfur reduction for removal and recovery of metals.

At low $\mathrm{pH}$, growth on acetate was faster than growth with $\mathrm{H}_{2} / \mathrm{CO}_{2}$ and also more sulfide was produced, indicating that the isolate did not suffer from acetic acid toxicity at low $\mathrm{pH}$, as has been found for other anaerobes. This ability is an interesting feature of Desulfurella strain TR1, as no described pure culture of acidophilic SRB can grow on acetate at low $\mathrm{pH}^{32,33}$ Instead, they accumulate acetic acid by incomplete oxidation of the substrates used (e.g., glycerol) which can create inhibitory effects at low $\mathrm{pH}^{33}$ Since acetic acid is toxic at low $\mathrm{pH}$, microorganisms able to utilize it can have an important role in detoxification. ${ }^{34}$ Kimura et al. ${ }^{35}$ showed acetate oxidation in an anaerobic syntrophic culture at low $\mathrm{pH}$ by the acetogenic strain PPBF, which was afterward described as Acidocella aromatica $^{36}$ and the sulfate reducer Desulfosporosinus strain M1, afterward described as Desulfosporosinus acididurans. ${ }^{14}$ Apart from the ecological role of acetate oxidizers, they can also have an important role in bioreactors treating acid mine drainage where acetate accumulation would occur. Other bacteria are able to reduce sulfur at low $\mathrm{pH}$ such as Acidithiobacillus ferrooxidans, which reduces sulfur at $\mathrm{pH} 2.5$ coupled to hydrogen utilization. ${ }^{37}$ However, A. ferrooxidans is unable to use acetate, and is inhibited at $5 \mathrm{mM}$ acetic acid. ${ }^{34}$

Sanchez-Andrea et al. ${ }^{38}$ quantified the abundance of diverse microbial populations inhabiting Tinto river and showed that Desulfurella spp. dominated in certain sediment layers (up to $36 \%$ of total cell count). Due to the reduction of sulfur compounds in those layers, the $\mathrm{pH}$ increases up to 6.2 and the redox potential decreases to $-246 \mathrm{mV}$, contrasting with the surroundings layers, some of them with $\mathrm{pH} 4.3$ and redox potential stated at $0 \mathrm{mV}$. Desulfurella related sequences are also found in other acidic environments. Burton and Norris ${ }^{39}$ analyzed sediment samples from acidic, geothermal pools on the Caribbean island of Montserrat and they reported that 43 out of 375 sequences related to Desulfurella species in sampling sites at $\mathrm{pH} 3$ and temperatures varying from 30 to $48{ }^{\circ} \mathrm{C}$. Kaksonen, et al. ${ }^{40}$ found some Desulfurella related sequences in a lactate-degrading enrichment at $\mathrm{pH} 4$ and $35{ }^{\circ} \mathrm{C}$. Willis et al. ${ }^{41}$ examined the bacterial diversity from the hot spring sediment Agua del Limón (with $\mathrm{pH}$ varying from $<1$ to 8 ) at the geothermal Caviahue-Copahue system and Desulfurella related sequences were also reported. Our results and the reported detection of Desulfurella suggest that it is an important player in the sulfur cycle not only at high temperature and close to neutral $\mathrm{pH}$ values, but also at moderate temperature and low $\mathrm{pH}$.

Of the types of elemental sulfur tested in this study, colloidal sulfur was the only one suitable for isolation of sulfur reducers at low $\mathrm{pH}$ on solid medium. In liquid medium, however, biosulfur showed the fastest growth of strain TR1. This may have a practical implication, as the use of biosulfur might lead to higher reduction rates in bioreactors, and thus smaller required bioreactor volumes and lower investment cost for the conversion. Biosulfur is produced at large-scale during biodesulfurisation of biogas and natural gas. ${ }^{42}$ The reuse of this biosulfur in acidophilic sulfur reduction processes for metal 
sulfide precipitation may therefore be favorable compared to the use of chemical sulfur.

The sulfide produced in the enrichments without any electron donor added, as well as in the enrichments with methanol is not coupled to oxidation of substrates in dissimilatory microbial sulfur reduction. Thus, microbial disproportionation of elemental sulfur can explain the formation of sulfide in both enrichments. Disproportionation of elemental sulfur to sulfide and sulfate eq 5 is an endergonic process at standard conditions ( $1 \mathrm{M}, 1 \mathrm{~atm})$; the free Gibbs energy change $\left(\Delta G^{0}\right)$ is $+33 \mathrm{~kJ} \mathrm{~mol}^{-1} \mathrm{~S}^{0}$. Although the Gibbs free energy of the reaction can be affected by the concentration of sulfide, limiting growth when it accumulates; the variation in $\mathrm{pH}$ values imposes stronger energetic impact. Performing calculations with eQuilibrator, ${ }^{43}$ when $2 \mathrm{mM}$ of sulfide is considered, the free Gibbs energy change of the reaction $\left(\Delta G^{\prime}\right)$ decreases from 58.3 to $-27.3 \mathrm{~kJ} \mathrm{~mol}^{-1} \mathrm{~S}^{0}$ when the $\mathrm{pH}$ increases from 4 to 7 , respectively. When the $\mathrm{pH}$ is kept constant (at 4, for example) and the sulfide concentration decreases from 2 to $0.2 \mathrm{mM}$, however, the Gibbs free energy decreases from 58.3 to $35.5 \mathrm{~kJ} \mathrm{~mol}^{-1} \mathrm{~S}^{0}$.

$$
4 \mathrm{~S}^{0}+4 \mathrm{H}_{2} \mathrm{O} \rightarrow \mathrm{SO}_{4}^{2-}+3 \mathrm{H}_{2} \mathrm{~S}+2 \mathrm{H}^{+}
$$

Some acidophilic microorganisms are shown to have a high heavy metal resistance, ${ }^{6,44,45}$ Desulfurella strain TR1 is rather resistant as well. Comparing with other sulfidogenic microorganisms, strain TR1 is somewhat higher resistant toward metals even at a $\mathrm{pH}$ as low as $\mathrm{pH} 3$ (Table 3), where actually

Table 3. Summary of Maximum Tolerated Concentration (mM) of Different Metals for Sulfate/Sulfur-Reducing Bacterial Cultures $^{a}$

$\begin{array}{ccccc}\text { metals } & \begin{array}{c}\text { Desulfovibrio } \\ \text { sp. }^{30}\end{array} & \begin{array}{c}\text { mixed } \\ \text { culture }\end{array} & \begin{array}{c}\text { mixed } \\ \text { culture }^{49}\end{array} & \begin{array}{c}\text { Desulfurella sp. strain } \\ \text { TR1 }\end{array} \\ \mathrm{Cu} & 0.06 & 0.31 & 0.2 & >0.5 \\ \mathrm{Ni} & 0.14 & 0.34 & \mathrm{NR} & 0.09 \\ \mathrm{~Pb} & \mathrm{NR} & 0.36 & \mathrm{NR} & 0.03 \\ \mathrm{Zn} & 0.3 & 0.04 & 0.31 & 0.09\end{array}$

${ }^{a} \mathrm{NR}$ stands for not reported.

other factors could also affect cell growth, such as the high proton concentration itself, the acetic acid, or the free hydrogen sulfide inhibition. ${ }^{46,47}$ Toxic concentrations of different heavy metals to bacteria involved in the sulfur cycle vary widely from a few to $100 \mathrm{mg} \mathrm{L}^{-1}$. Cabrera, et al. ${ }^{24}$ reported for Desulfovibrio spp. in batch culture precipitation levels in the highest tolerated concentration of copper, nickel and zinc in a range of $45-71 \%$ at $0.06 \mathrm{mM}, 96 \%$ at $0.14 \mathrm{mM}$ and $9-93 \%$ at $0.3 \mathrm{mM}$, respectively. Hao, et al. $^{48}$ assessed the inhibitory metal concentrations toward sulfate-reducing communities in wastewaters. They indicated critical free metal concentrations for inhibition of sulfate reduction as being $0.36,0.04,0.31$, and 0.34 $\mathrm{mM}$ for lead, zinc, copper and nickel, respectively. The inhibitory metal concentrations toward Desulfurella strain TR1 were $0.04,0.2,>0.5$ and $2.6 \mathrm{mM}$ for lead, zinc, copper and nickel, respectively. In practice, in a continuous sulfurreducing bioreactor for precipitation of heavy metals at $\mathrm{pH} 3-$ 4 , there should be at any time, several $\mathrm{mM}$ of sulfide in solution for process stability. Especially for metal sulfides, like $\mathrm{ZnS}$, which are slightly soluble at such pH levels, toxicity is most relevant. Figure 4-d2 shows that at $0.09 \mathrm{mM}$ added $\mathrm{Zn}^{2+}$ there is still sulfide formation, but only about $1 / 3$ of the zinc ultimately precipitates. Apparently, about $0.06 \mathrm{mM}$ zinc remains in solution despite the excess of sulfide, confirming the higher solubility of zinc at lower $\mathrm{pH}$. This shows that sulfur reduction can still proceed with some zinc in solution, which is beneficial for practical feasibility. For $\mathrm{Pb}$, this is clearly different, once it does not precipitate completely, it becomes toxic.

Compared to sulfate, sulfur requires 4 times less electron donor to generate the same amount of sulfide, which would reduce the need of electron donors and therefore the operating costs of biological sulfide generation technology. Although this results in some additional cost for sulfur (whereas sulfate is normally present in sufficiently high concentrations in the mining and metallurgical waste), the net cost reduction is large. For example, Hedrich and Johnson ${ }^{49}$ performed iron oxidation and sulfate reduction to precipitate metals at low $\mathrm{pH}$ in modular reactors. The analysis of costs revealed that a projected $42 \mathrm{~m}^{3}$ sulfidogenic reactor needed to treat $1 \mathrm{~m}^{3}$ mine water with glycerol as electron donor, would produce $3.9 \mathrm{~mol}$ of sulfide in the process. Thus, considering the stoichiometry of the glycerol oxidation coupled to sulfate reduction (eq 6), the reactor would require $208.5 \mathrm{~g}$ of glycerol $(2.3 \mathrm{~mol})$, implying $0.5 \$$ as cost for this reagent, if we consider the market price of the glycerol as $2400 \$ /$ ton.

If sulfur is applied as electron acceptor, about $0.13 \mathrm{~kg}$ of it would be required to form the same amount of sulfide in a 42 $\mathrm{m}^{3}$ reactor. Considering the market price of sulfur as $61 \$ /$ ton, $0.008 \$$ is the additional cost for the process. However, as sulfur reduction requires four times less electron donors (eq 7), the same amount of sulfide is formed with only $52.1 \mathrm{~g}$ of glycerol, and a global reduction in costs of $0.37 \$$ per $\mathrm{m}^{3}$ of mine water treated is achieved.

$$
\begin{aligned}
& 4 \mathrm{C}_{3} \mathrm{H}_{8} \mathrm{O}_{3}+7 \mathrm{SO}_{4}{ }^{2-} \rightarrow 7 \mathrm{H}_{2} \mathrm{~S}+12 \mathrm{CO}_{2}+16 \mathrm{H}_{2} \mathrm{O} \\
& \mathrm{C}_{3} \mathrm{H}_{8} \mathrm{O}_{3}+7 \mathrm{~S}+3 \mathrm{H}_{2} \mathrm{O} \rightarrow 7 \mathrm{H}_{2} \mathrm{~S}+3 \mathrm{CO}_{2}
\end{aligned}
$$

As an estimated market price of copper as $5900 \$ /$ ton and considering $0.46 \mathrm{~kg}$ of this metal being recovered by the amount of sulfide produced in the process, a return of $2.71 \$$ per $\mathrm{m}^{3}$ of mine treated can be obtained.

In summary, the metal tolerance, broad temperature and $\mathrm{pH}$ range of Desulfurella strain TR1 show the feasibility to apply Desulfurella strain TR1 to perform sulfur reduction to precipitate and recover heavy metals from acidic wastewater and mining water, without the need to neutralize the water before treatment. The growth and activity at such a broad range of $\mathrm{pH}$ makes the operation of reactor for selective precipitation of metals such as zinc, copper, nickel, lead and iron at controlled $\mathrm{pH}$ feasible.

\section{ASSOCIATED CONTENT}

\section{Supporting Information}

The Supporting Information is available free of charge on the ACS Publications website at DOI: 10.1021/acs.est.5b03346.

Figures S1-S4, Tables S1 and S2 (PDF)

\section{AUTHOR INFORMATION}

\section{Corresponding Author}

*Phone/fax: +31 317483115 14/+31 317 483829; e-mail: irene.sanchezandrea@wur.nl.

\section{Notes}

The authors declare no competing financial interest. 


\section{ACKNOWLEDGMENTS}

We thank CNPq (Conselho Nacional de Desenvolvimento Cientifico e Tecnológico), organization of the Brazilian Government for supporting the doctoral study program for the development of Science and Technology; Esther Velasco for providing sediment samples; and Ton van Gelder and Ricardo Pereira for their laboratory help. Research of I. Sánchez-Andrea. and A.J.M. Stams is financed by ERC grant project 323009, and Gravitation grant project 024.002.002 from The Netherlands Ministry of Education, Culture and Science.

\section{REFERENCES}

(1) Johnson, D. B.; Hallberg, K. B. Acid mine drainage remediation options: a review. Sci. Total Environ. 2005, 338 (1-2), 3-14.

(2) Tang, K.; Baskaran, V.; Nemati, M. Bacteria of the sulphur cycle: An overview of microbiology, biokinetics and their role in petroleum and mining industries. Biochem. Eng. J. 2009, 44 (1), 73-94.

(3) Sanchez-Andrea, I.; Knittel, K.; Amann, R.; Amils, R.; Sanz, J. L. Quantification of Tinto River sediment microbial communities: importance of sulfate-reducing bacteria and their role in attenuating acid mine drainage. Appl. Environ. Microb. 2012, 78 (13), 4638-4645.

(4) Koschorreck, M. Microbial sulphate reduction at a low pH. FEMS Microbiol. Ecol. 2008, 64 (3), 329-342.

(5) Johnson, D. B. Biodiversity and ecology of acidophilic microorganisms. FEMS Microbiol. Ecol. 1998, 27 (4), 307-317.

(6) Ňancucheo, I.; Johnson, D. B. Selective removal of transition metals from acidic mine waters by novel consortia of acidophilic sulfidogenic bacteria. Microb. Biotechnol. 2012, 5 (1), 34-44.

(7) Liamleam, W.; Annachhatre, A. P. Electron donors for biological sulfate reduction. Biotechnol. Adv. 2007, 25 (5), 452-463.

(8) Younger, P. L.; Jayaweera, A.; Elliot, A.; Wood, R.; Amos, P.; Daugherty, A. J.; Martin, A.; Bowden, L.; Aplin, A. C.; Johnson, D. B. Passive treatment of acidic mine waters in subsurface-flow systems: exploring RAPS and permeable reactive barriers. Land Contam. Reclamat. 2003, 11 (2), 127-135.

(9) Weijma, J.; Copini, C. F. M.; Buisman, C. J. N.; Schultz, C. E., Biological recovery of metals, sulfur and water in the mining and metallurgical industry. In Water Recycling and Recovery in Industry; Lens, P. N. L., Hulshoff Pol, L. W., Wilderer, P., Asano, T., Eds.; IWA Publishing: London, 2002; pp 605-622.

(10) Florentino, A. P.; Weijma, J.; Stams, A. J. M.; Sánchez-Andrea, I., Ecophysiology and application of acidophilic sulfur-reducing microorganisms. In Biotechnology of Extremophiles: Advances and Challenges; Rampelotto, P. H., Ed.; Springer International Publishing: Switzerland, 2016.

(11) Steudel, R.; Eckert, B., Solid sulfur allotropes sulfur allotropes. In Elemental Sulfur and Sulfur-Rich Compounds I; Springer: Berlin Heidelberg, 2003; Vol. 230, pp 1-80:

(12) Breher, F. Elemental sulfur and sulfur-rich compounds, Angewandte Chemie. International ed.; WILEY-VCH Verlag, 2004; Vol. 43, p 3629a-3630.

(13) Lopez-Archilla, A. I.; Marin, I.; Amils, R. Microbial community composition and ecology of an acidic aquatic environment: The Tinto River, Spain. Microbiol. Ecol. 2001, 41 (1), 20-35.

(14) Sánchez-Andrea, I.; Stams, A. J. M.; Hedrich, S.; Nancucheo, I.; Johnson, D. B. Desulfosporosinus acididurans sp. nov.: an acidophilic sulfate-reducing bacterium isolated from acidic sediments. Extremophiles 2015, 19 (1), 39-47.

(15) Sanchez-Andrea, I.; Sanz, J. L.; Stams, A. J. Microbacter margulisiae gen. nov., sp. nov., a propionigenic bacterium isolated from sediments of an acid rock drainage pond. Int. J. Syst. Evol. Microbiol. 2014, 64 (12), 3936-42.

(16) Quast, C.; Pruesse, E.; Yilmaz, P.; Gerken, J.; Schweer, T.; Yarza, P.; Peplies, J.; Glockner, F. O. The SILVA ribosomal RNA gene database project: improved data processing and web-based tools. Nucleic Acids Res. 2013, 41 (Database issue), D590-6.
(17) Sánchez-Andrea, I.; Stams, A. J. M.; Amils, R; Sanz, J. L. Enrichment and isolation of acidophilic sulfate-reducing bacteria from Tinto River sediments. Environ. Microbiol. Rep. 2013, 5 (5), 672-678.

(18) Stams, A. J. M.; Van Dijk, J. B.; Dijkema, C.; Plugge, C. M. Growth of syntrophic propionate-oxidizing bacteria with fumarate in the absence of methanogenic bacteria. Appl. Environ. Microbiol. 1993, 59 (4), 1114-1119.

(19) Cline, J. D. Spectrophotometric determination of hydrogen sulfide in natural waters. Limnol. Oceanogr. 1969, 14 (3), 454-458.

(20) Surkov, A. V.; Bottcher, M. E.; Kuever, J. Stable sulfur isotope fractionation during the reduction of thiosulfate by Dethiosulfovibrio russensis. Arch. Microbiol. 2000, 174 (6), 448-451.

(21) Tuovinen, O. H. A method for the preparation of solidified colloidal sulphur media. Zentralbl. Bakteriol., Parasitenkd., Infektionskrankh. Hyg., Abt. 2, Naturwiss.: Mikrobiol. Landwirtsch., Technol. Umweltschutzes 1979, 134 (1), 108-109.

(22) Boyd, E. S.; Druschel, G. K. Involvement of intermediate sulfur species in biological reduction of elemental sulfur under acidic, hydrothermal conditions. Appl. Environ. Microbiol. 2013, 79 (6), 2061-2068.

(23) Boulegue, J. Solubility of elemental sulfur in water at $298 \mathrm{~K}$. Phosphorus Sulfur Relat. Elem. 1978, 5 (1), 127-128.

(24) Cabrera, G.; Perez, R.; Gomez, J. M.; Abalos, A.; Cantero, D. Toxic effects of dissolved heavy metals on Desulfovibrio vulgaris and Desulfovibrio sp. strains. J. Hazard. Mater. 2006, 135 (1-3), 40-46.

(25) Zwietering, M. H.; Jongenburger, I.; Rombouts, F. M.; van 't Riet, K. Modeling of the bacterial growth curve. Appl. Environ. Microbiol. 1990, 56 (6), 1875-1881.

(26) Bonch-Osmolovskaya, E. A.; Sokolova, T. G.; Kostrikina, N. A.; Zavarzin, G. A. Desulfurella acetivorans gen. nov. and sp. nov. - a new thermophilic sulfur-reducing eubacterium. Arch. Microbiol. 1990, 153, $151-155$.

(27) Miroshniehenko, M. L.; Gongadze, G. A.; Lysenko, A. M.; Bonch-Osmolovskaya, E. A. Desulfurella multipotens sp. nov., a new sulfur-respiring thermophilic eubacterium from Raoul Island (Kermadec archipelago, New Zealand). Arch. Microbiol. 1994, 161, 88-93.

(28) Miroshnichenko, M. L.; Rainey, F. A.; Hippe, H.; Chernyh, N. A.; Kostrikina, N. A.; Bonch-Osmolovskaya, E. A. Desulfurella karnchatkensis sp. nov. and Desulfurella propionica sp. nov., new sulfur respiring thermophilic bacteria from Kamchatka thermal environments. Int. J. Syst. Bacteriol. 1998, 48, 475-479.

(29) Yarza, P.; Yilmaz, P.; Pruesse, E.; Glockner, F. O.; Ludwig, W.; Schleifer, K.-H.; Whitman, W. B.; Euzeby, J.; Amann, R.; RosselloMora, R. Uniting the classification of cultured and uncultured bacteria and archaea using 16S rRNA gene sequences. Nat. Rev. Microbiol. 2014, 12 (9), 635-645.

(30) Brito, E. M.; Villegas-Negrete, N.; Sotelo-Gonzalez, I. A.; Caretta, C. A.; Goni-Urriza, M.; Gassie, C.; Hakil, F.; Colin, Y.; Duran, R.; Gutierrez-Corona, F.; Pinon-Castillo, H. A.; Cuevas-Rodriguez, G.; Malm, O.; Torres, J. P.; Fahy, A.; Reyna-Lopez, G. E.; Guyoneaud, R. Microbial diversity in Los Azufres geothermal field (Michoacan, Mexico) and isolation of representative sulfate and sulfur reducers. Extremophiles 2014, 18 (2), 385-398.

(31) Alazard, D.; Joseph, M.; Battaglia-Brunet, F.; Cayol, J. L.; Ollivier, B. Desulfosporosinus acidiphilus sp. nov.: a moderately acidophilic sulfate-reducing bacterium isolated from acid mining drainage sediments: New taxa: Firmicutes (Class Clostridia, Order Clostridiales, Family Peptococcaceae). Extremophiles 2010, 14 (3), 305312.

(32) Rosenberg, E.; DeLong, E.; Lory, S.; Stackebrandt, E.; Thompson, F.; Rabus, R.; Hansen, T. A.; Widdel, F., Dissimilatory sulfate- and sulfur-reducing prokaryotes. In The Prokaryotes; Springer: Berlin Heidelberg, 2013; pp 309-404.

(33) Sanchez-Andrea, I.; Sanz, J. L.; Bijmans, M. F. M.; Stams, A. J. M. Sulfate reduction at low $\mathrm{pH}$ to remediate acid mine drainage. $J$. Hazard. Mater. 2014, 269, 98-109.

(34) Tuttle, J. H.; Dugan, P. R. Inhibition of growth, iron, and sulfur oxidation in Thiobacillus ferrooxidans by simple organic compounds. Can. J. Microbiol. 1976, 22 (5), 719-730. 
(35) Kimura, S.; Hallberg, K. B.; Johnson, D. B., Sulfidogenesis in low $\mathrm{pH}(3.8-4.2)$ media by a mixed population of acidophilic bacteria $\backslash$. Biodegradation 2006, 17 (2), 159-167. DOI: 10.1007/s10532-0053050-4.

(36) Jones, R. M.; Hedrich, S.; Johnson, D. B. Acidocella aromatica sp. nov.: an acidophilic heterotrophic alphaproteobacterium with unusual phenotypic traits. Extremophiles 2013, 17 (5), 841-850.

(37) Jameson, E.; Rowe, O. F.; Hallberg, K. B.; Johnson, D. B. Sulfidogenesis and selective precipitation of metals at low $\mathrm{pH}$ mediated by Acidithiobacillus spp. and acidophilic sulfate-reducing bacteria. Hydrometallurgy 2010, 104 (3-4), 488-493.

(38) Sanchez-Andrea, I.; Rodriguez, N.; Amils, R.; Sanz, J. L. Microbial diversity in anaerobic sediments at Rio Tinto, a naturally acidic environment with a high heavy metal content. Appl. Environ. Microbiol. 2011, 77 (17), 6085-6093.

(39) Burton, N. P.; Norris, P. R. Microbiology of acidic, geothermal springs of Montserrat: environmental rDNA analysis. Extremophiles 2000, 4, 315-320.

(40) Kaksonen, A. H.; Plumb, J. J.; Franzmann, P. D.; Puhakka, J. A. Simple organic electron donors support diverse sulfate-reducing communities in fluidized-bed reactors treating acidic metal- and sulfate-containing wastewater. FEMS Microbiol. Ecol. 2004, 47 (3), 279-289.

(41) Willis, G.; Hendrich, S.; Ñancucheo, I.; Johnson, D. B.; Donati, E. Microbial Diversity in Acidic Anaerobic sediments at the geothermal Caviahue-Copahue system, Argentina. Adv. Mater. Res. 2013, 825, 710.

(42) Janssen, A. J. H.; Ruitenberg, R; Buisman, C. J. N. Industrial applications of new sulfur biotechnology. Water Sci. Technol. 2001, 44 (8), 85-90.

(43) Flamholz, A.; Noor, E.; Bar-Even, A.; Milo, R. eQuilibrator - the biochemical thermodynamics calculator. Nucleic Acids Res. 2012, 40, D770-5.

(44) Dopson, M.; Baker-Austin, C.; Koppineedi, P. R.; Bond, P. L. Growth in sulfidic mineral environments: metal resistance mechanisms in acidophilic microorganisms. Microbiology 2003, 149 (8), 19591970.

(45) Dopson, M.; Holmes, D. S. Metal resistance in acidophilic microorganisms and its significance for biotechnologies. Appl. Microbiol. Biotechnol. 2014, 98 (19), 8133-8144.

(46) Dopson, M.; Ossandon, F.; Lövgren, L.; Holmes, D. S. Metal resistance or tolerance? Acidophiles confront high metal loads via both abiotic and biotic mechanisms. Front. Microbiol. 2014, 5 (157), 1-4.

(47) Utgikar, V. P.; Harmon, S. M.; Chaudhary, N.; Tabak, H. H.; Govind, R.; Haines, J. R. Inhibition of sulfate-reducing bacteria by metal sulfide formation in bioremediation of acid mine drainage. Environ. Toxicol. 2002, 17 (1), 40-48.

(48) Hao, O. J.; Huang, L.; Chen, J. M.; Buglass, R. L. Effects of metal additions on sulfate reduction activity in wastewaters. Toxicol. Environ. Chem. 1994, 46 (4), 197-212.

(49) Hedrich, S.; Johnson, D. B. Remediation and selective recovery of metals from acidic mine waters using novel modular bioreactors. Environ. Sci. Technol. 2014, 48 (20), 12206-12212. 